\title{
Effects of Gas Nitriding Temperature on the Surface Properties of a High Manganese TWIP Steel
}

\author{
Xiaoyun Yuan ${ }^{1}$, Yang Zhao ${ }^{2}$, Xing $\mathrm{Li}^{1}$ and Liqing Chen ${ }^{1, *}$ \\ 1 State Key Laboratory of Rolling and Automation, Northeastern University, Shenyang 110819, China; \\ yuanxy_ral@sina.com (X.Y.); neulixing@163.com (X.L.) \\ 2 School of Materials Science and Engineering, Northeastern University, Shenyang 110819, China; \\ zhaoyang0323@smm.neu.edu.cn \\ * Correspondence: lqchen@mail.neu.edu.cn; Tel.: +86-24-83681819
}

Academic Editor: Rebecca L. Higginson

Received: 18 February 2017; Accepted: 17 March 2017; Published: 21 March 2017

\begin{abstract}
The effects of gas nitriding temperature on the cross section morphology, element nitrogen distribution, and surface layer compositions of a cold rolled and pre-strained high manganese austenitic TWIP steel 25Mn-3Cr-3Al-0.3C-0.01N and the corresponding anti-corrosion ability have been studied. The results show that, depending on nitriding temperature, the distribution of element nitrogen and main phase compositions are significantly different in the nitriding layers. At a temperature lower than $500{ }^{\circ} \mathrm{C}$, the main composition in the modified layer is S-phase and the nitrogen concentration linearly decreases from the surface to the center, while $\mathrm{Fe}_{4} \mathrm{~N}$ forms with S-phase and a step-like distribution of nitrogen content is present at nitriding temperature of $600{ }^{\circ} \mathrm{C}$. Caused by the increasing of modified layer thickness and the formation of S-phase and $\mathrm{Fe}_{4} \mathrm{~N}$, the surface hardness was obviously enhanced. Anodic polarization curves in $3.5 \mathrm{wt}$. \% NaCl solution indicate that the nitrided processes have a tremendous modification effect on anti-corrosion ability. Moreover, the increase of (111) oriented grain, caused by the elevated nitriding temperature, has a positive effect on the corrosion resistance.
\end{abstract}

Keywords: twinning-induced plasticity (TWIP) steel; gas nitriding; polarization curve; anti-corrosion ability

\section{Introduction}

It is well known that austenitic stainless steels possess excellent corrosion resistance, but the low hardness and poor wear resistance seriously limit their applications. Thus, surface treatments have been extensively used to improve the surface quality, especially the hardness and wear resistance. As a usual method, nitriding processes containing gas and ion nitriding are widely applied to treat and modify the surface properties of ferrous materials. Unfortunately, most of the surface modification treatments fail to improve the mechanical properties without loss of corrosion resistance.

For most steels, temperature is one of the main influencing factors on the phase composition and properties of the nitrided layer. A study by Yetim et al. [1] shows that when the nitriding temperature is higher than $500{ }^{\circ} \mathrm{C}$, caused by the formation of $\mathrm{CrN}$ and $\gamma^{\prime}-\mathrm{Fe}_{4} \mathrm{~N}$, the corrosion resistance of the nitrided layer decreases. Other results $[2,3]$ suggest that, when nitriding temperature ranges from $500{ }^{\circ} \mathrm{C}$ to $650{ }^{\circ} \mathrm{C}, \mathrm{CrN}$ forms in the nitrided layer and increase the hardness and wear resistance of the modified layer. However, the consumption of $\mathrm{Cr}$ leads to chromium dilution in the matrix and results in a sharp weakening of corrosion resistance. Therefore, it has much practical significance to improve the surface hardness and wear resistance without decreasing the anti-corrosion ability during the surface nitridation treatment. Extensive studies of nitriding technology have shown that an expanded austenite metastable phase can form at a relatively low nitriding temperature 
$\left(\sim 450{ }^{\circ} \mathrm{C}\right)$ [4-7] and this phenomenon attracted more and more attention [8-10]. For conventional types of stainless steels-e.g., 316 and 304-the expanded austenite formed at $450{ }^{\circ} \mathrm{C}$ can improve the surface hardness and wear resistance without loss of corrosion resistance [6,7]. The research on this metastable phase can be traced back to 1986, first proposed as "S-phase" by Ichii et al. [11]. Marchev et al. [12,13] then identified the structure of this phase as body centered tetragonal (bct) [12] and named it " $m$-phase" [13]. The formation of this expanded austenite is ascribed to the presence of the nitrogen atoms in the steel surface. Rather than combining with elements in the matrix to form nitrides, the nitrogen atoms diffuse into the face-centered cubic (fcc) lattice $[14,15]$ at lower temperatures. Thus, it is also called "N-expanded austenite" [16-18]. The nitrided layer with this metastable phase possesses good corrosion resistance with the hardness improved four to five times and the wear resistance enhanced by several orders of magnitude [19-21].

It is recognized that some specific nitriding processes could produce a nitrided layer that possess higher hardness, excellent wear, and good corrosion resistance [22-24]. In our previous study, we reported on a $\mathrm{Cr}$-containing $\mathrm{Fe}-\mathrm{Mn}$ - $\mathrm{Al}-\mathrm{C}$ high manganese austenitic twinning induced plasticity (TWIP) steel showed better mechanical properties as compared with conventional stainless steels [25]. In addition, this TWIP steel possesses excellent resistance to oxidation and has potential for partially replacing austenitic stainless steels [26]. If the anti-corrosion ability of this austenitic TWIP steel is further improved, it will have wider applications. Nitriding process may lead to surface hardening so that the subsequent plastic deformation may cause surface cracking. Thus, it should be carried out as the last step in a manufacturing procedure. Hence, in this paper the effect of gas nitriding temperature on pre-strained high manganese austenitic steel Fe-25Mn-3Cr-3Al-0.3C-0.01N (in wt. pct) has been studied. The aim of this study is to research the characteristics of the nitrided layers and their effect on the anti-corrosion ability of this TWIP steel.

\section{Materials and Methods}

The cold-rolled steel sheets used in this study were obtained through processes same as in our previous research [26], and then annealed at $800{ }^{\circ} \mathrm{C}$ for $20 \mathrm{~min}$. The chemical composition is shown in Table 1. The yield and ultimate tensile strengths of this steel sheet, measured by room-temperature uniaxial tensile test, are $313.3 \mathrm{MPa}$ and $629.3 \mathrm{MPa}$, respectively, while the elongation is $44.3 \%$. An amount of plastic deformation strained at room temperature $(\sim 20 \%)$ was exerted on the cold-rolled and annealed austenitic TWIP steel sheets prior to nitriding. As for the gas-nitriding, the chamber of the furnace containing specimens was firstly degassed and backfilled with ammonia before heating. Then it was heated up to $400-600{ }^{\circ} \mathrm{C}$ from room temperature at a rate of $6{ }^{\circ} \mathrm{C} / \mathrm{min}$. The nitriding experiment was conducted at 400,500 and $600{ }^{\circ} \mathrm{C}$ for $2 \mathrm{~h}$. The flow rate of the ammonia gas into the chamber of the furnace was controlled as $300 \mathrm{~mL} / \mathrm{min}$ during all the nitriding processes. After that, the samples were furnace cooled to room temperature.

Table 1. Chemical composition of the high manganese TWIP steel (in wt. \%).

\begin{tabular}{cccccccccc}
\hline Element & $\mathbf{C}$ & $\mathbf{M n}$ & $\mathbf{C r}$ & $\mathbf{A l}$ & $\mathbf{N}$ & $\mathbf{S i}$ & $\mathbf{P}$ & $\mathbf{S}$ & $\mathbf{F e}$ \\
\hline Percentage & 0.33 & 25.9 & 2.96 & 2.83 & 0.01 & 0.27 & 0.005 & 0.008 & Bal. \\
\hline
\end{tabular}

The cross section and surface morphology of nitrided layers was observed by a scanning electron microscopy (SEM, ZEISS Ultra 55, Zeiss, Hallbergmoos, German) equipped with electron back-scattered diffraction (EBSD). The phase composition of the nitrided layer was determined by an X-ray diffractometer (XRD, Bruker D8 Discover, Bruker, Karlsruhe, German) with $\mathrm{Cu}$ K $\alpha$ radiation $\left(\lambda_{\mathrm{K} \alpha 1}=0.154056 \mathrm{~nm}\right.$ and $\left.\lambda_{\mathrm{K} \alpha 2}=0.154439 \mathrm{~nm}\right)$. The elemental distribution was analyzed by an electron probe microanalyzer (EPMA, JEOL JXA-8530F, JEOL, Tokyo, Japan) equipped with a wavelength dispersive spectrometer (WDS). Vickers hardness was measured by a universal sclerometer (KB3000BVRZ-SA, KB, Hochdorf-Assenheim, Germany) under a load of $5 \mathrm{kgf}$. The anti-corrosion 
ability of the steel sheets was characterized by the typical polarization curves in $3.5 \% \mathrm{NaCl}$ solution at $25^{\circ} \mathrm{C}$ through CorrTest 4 electrochemical workstation (CorrTest, Wuhan, China).

\section{Results and Discussion}

\subsection{Microstructure}

The secondary electron images showing the cross section morphology of the nitrided steel sheets are provided in Figure 1. We can see from Figure 1 that when nitriding temperature is lower than $500{ }^{\circ} \mathrm{C}$, the demarcation between the nitriding layer and the matrix is obvious. However, it is not apparent when the nitriding temperature increased to $600{ }^{\circ} \mathrm{C}$. In addition, the thickness of the nitrided layer also depends largely on nitriding temperature. An obviously increased layer thickness was obtained with the elevated nitriding temperature. Table 2 lists the mean thicknesses of the nitriding layers of this steel sheet nitrided at various temperatures. Only a 3-4 $\mu \mathrm{m}$ nitrided layer in thickness could be obtained when nitrided at $400{ }^{\circ} \mathrm{C}$ for $2 \mathrm{~h}$. While the nitriding temperature was raised to $500^{\circ} \mathrm{C}$ and $600^{\circ} \mathrm{C}$, the thickness of the nitrided layers reached $10-15 \mu \mathrm{m}$ and $40-55 \mu \mathrm{m}$, respectively.

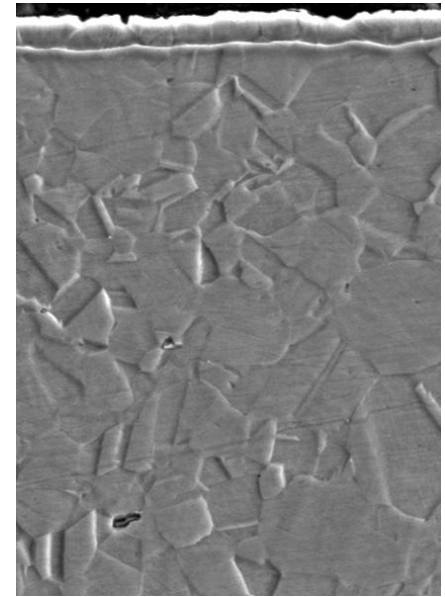

(a)

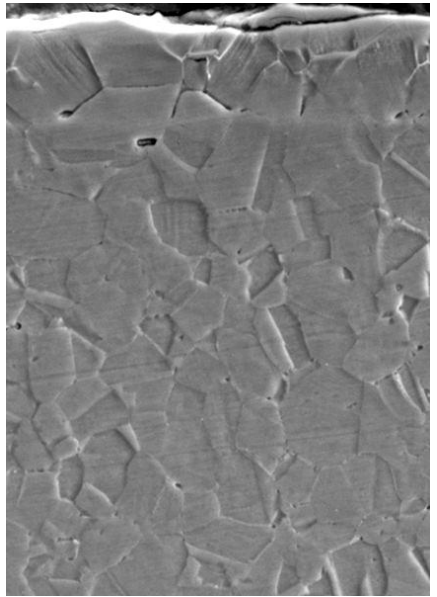

(b)

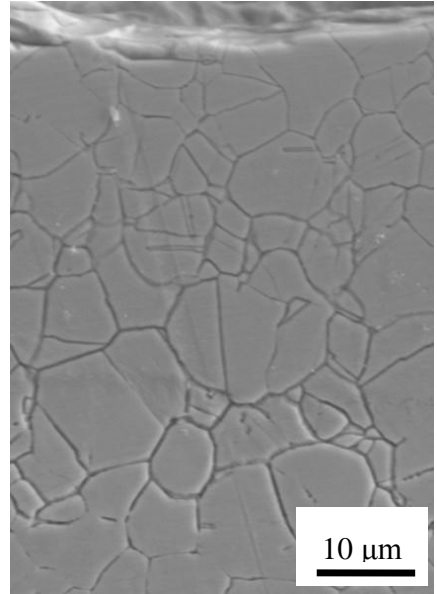

(c)

Figure 1. Scanning electron microscopy (SEM) cross sectional micrograph of the high manganese TWIP steel nitrided at (a) $400{ }^{\circ} \mathrm{C}$, (b) $500{ }^{\circ} \mathrm{C}$, (c) $600^{\circ} \mathrm{C}$ for $2 \mathrm{~h}$.

Figure 2 displays the elemental composition of the steel sheets surface before and after nitriding processes. Comparison with Figure $2 \mathrm{a}, \mathrm{b}$ demonstrates the diffusion of element $\mathrm{N}$ into the specimen surface by the variation of elemental composition when nitrided at $400-600{ }^{\circ} \mathrm{C}$ for $2 \mathrm{~h}$.

Nitrogen concentration depth profiles of the nitrided specimens measured by WDX are shown in Figure 3. It is obvious that for the specimens nitrided at $400-600{ }^{\circ} \mathrm{C}$, the concentration of nitrogen decreases in a different way from the surface to center. When the nitriding temperature is lower than $500{ }^{\circ} \mathrm{C}$, the concentration of nitrogen in the modified layers approximately linearly decreased. When the nitriding temperature is $600{ }^{\circ} \mathrm{C}$, a step-like distribution of nitrogen was observed. This step-like distribution was also observed in the surface modified layer of AISI 316L stainless steel plates [27,28]. In another study on plasma-sprayed AISI 316L coating [29], this step-like distribution was not found. It is because, compared with nitrogen, the solid oxides in the coating interacted with the chromium atoms more strongly. There is no oxide in the gas-nitriding modified layers of this studied steel sheet. Hence, the modified layer formed in a similar way to that of AISI 316L stainless steel plate at the nitriding temperature of $600{ }^{\circ} \mathrm{C}[27,28]$, such that chromium atoms bound to nitrogen in S-phase bring about the step-like distribution of nitrogen. 


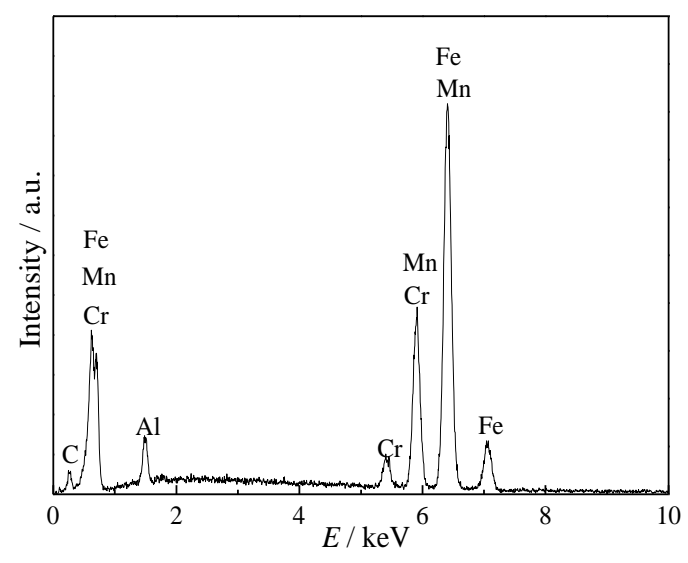

(a)

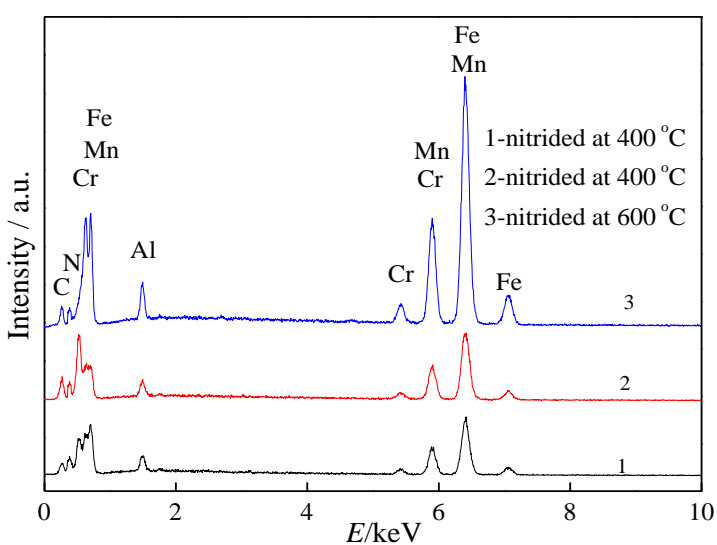

(b)

Figure 2. Element composition in the surface of the high manganese austenitic TWIP steel sheets before being nitrided (a) and after being nitrided at different temperatures (b).

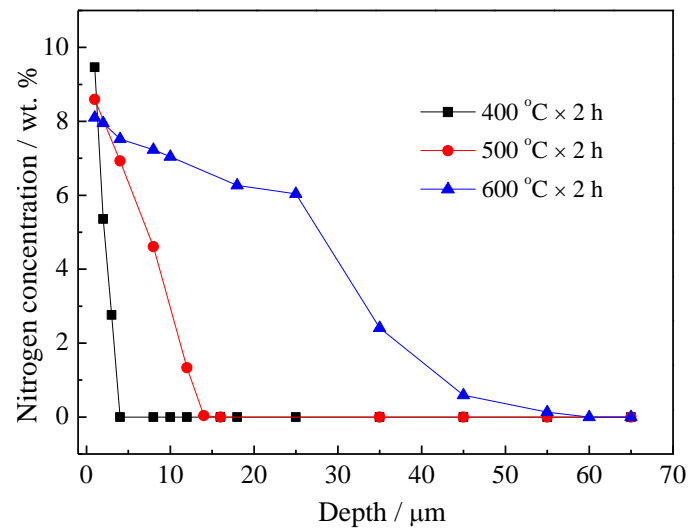

Figure 3. Sectional distribution of nitrogen in the high-manganese TWIP steel treated at various temperatures.

The hardness values of the nitrided sample surfaces, along with that of the as-resaved steel are listed in Table 2. After nitriding treatments, the hardness of this high-manganese austenitic TWIP steel sheet was obviously enhanced. The hardness value of the untreated steel sheet is measured as $271 \mathrm{HV}$ while the after-nitriding steel sheets are 280-338 HV. Furthermore, when the nitriding temperature is $600{ }^{\circ} \mathrm{C}$, the hardness of the modified surface is increased much more than that at temperatures lower than $500^{\circ} \mathrm{C}$.

Table 2. Dependence of the nitrided layer thickness and surface hardness on nitriding temperature.

\begin{tabular}{cccc}
\hline Sample No. & Nitrding Temperature $\left({ }^{\circ} \mathbf{C}\right)$ & Modified Layer Thickness $(\mu \mathrm{m})$ & Hardness $(\mathbf{H V})$ \\
\hline Untreated & - & - & 271 \\
1 & 400 & $3-4$ & 280 \\
2 & 500 & $10-15$ & 292 \\
3 & 600 & $40-55$ & 338 \\
\hline
\end{tabular}

The hardness of the modified layer depends on substrate structure, alternation of crystal lattice structure, and the phase components of the modified layers. In this study, the samples nitrided at different temperatures were received from the same steel sheet. Thus, the influence of substrate structure can be neglected. Therefore, the surface hardness depends largely on the diffusion of nitrogen atoms. It is reported that the interstitial nitrogen atoms in fcc lattice may lead to lattice distortion 
and form S-phase with higher hardness [30,31]. Koskinen et al. [32] reported that the broadening and shoulders around the austenite (111) peak are probably associated with the $\gamma-\mathrm{N}$ supersaturated phases. As the XRD analyses results show in Figure 4, all the three nitriding processes bring about the formation of S-phase in the nitrided layers. Moreover, when nitrided temperature was raised to $600{ }^{\circ} \mathrm{C}, \mathrm{Fe}_{4} \mathrm{~N}$ formed with S-phases in the nitrided layer. It is suggested that S-phase including $\mathrm{Fe}_{4} \mathrm{~N}$ could be formed more frequently on a high-temperature gas-nitriding process [33]. The nitrided layer containing $\mathrm{Fe}_{4} \mathrm{~N}+\mathrm{S}$ dual phases is harder than the modified layer containing a single S-phase. The above results are associated with the increasing of surface hardness listed in Table 2.

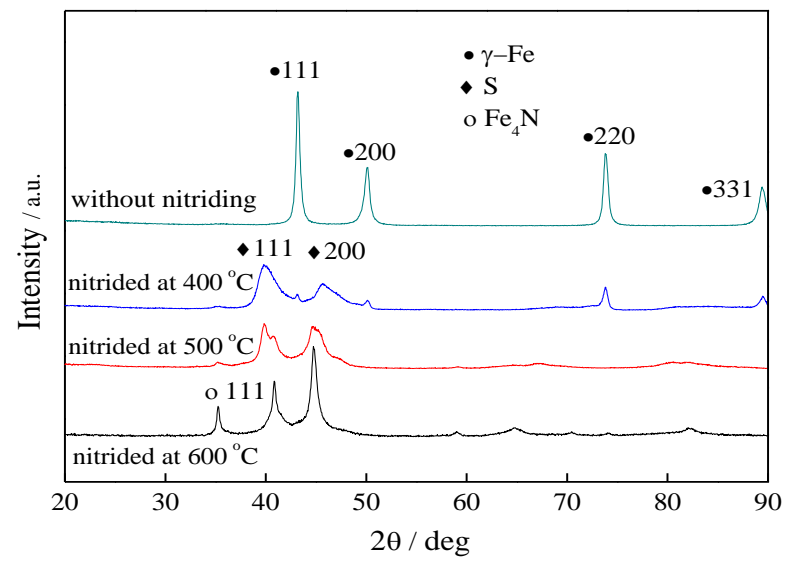

Figure 4. XRD pattern of the high manganese TWIP steel surface nitrided at different temperatures.

\subsection{Anti-Corrosion Properties}

Figure 5 shows the typical polarization curves of the nitrided samples in $3.5 \mathrm{wt} . \% \mathrm{NaCl}$ solution. As a reference, a typical polarization curve of the untreated sample is also presented under the same experimental conditions. It is obvious that with the increase of nitriding temperatures, the corrosion potentials are shifted to the positive side. The $\mathrm{E}_{\text {corr }}$ and $\mathrm{I}_{\text {corr }}$ listed in Table 3 are obtained by using of least square method. It can be found that, after nitriding processes, the corrosion current was decreased by over two orders of magnitude from $1.9 \times 10^{-5} \mathrm{~A} / \mathrm{cm}^{2}$ (untreated alloy) to $5.2 \times 10^{-7} \mathrm{~A} / \mathrm{cm}^{2}$. This indicates that the nitriding processes enhanced the corrosion resistance of the high manganese austenitic TWIP steel. Moreover, the increase of nitriding temperatures has a positive effect on the corrosion resistance.

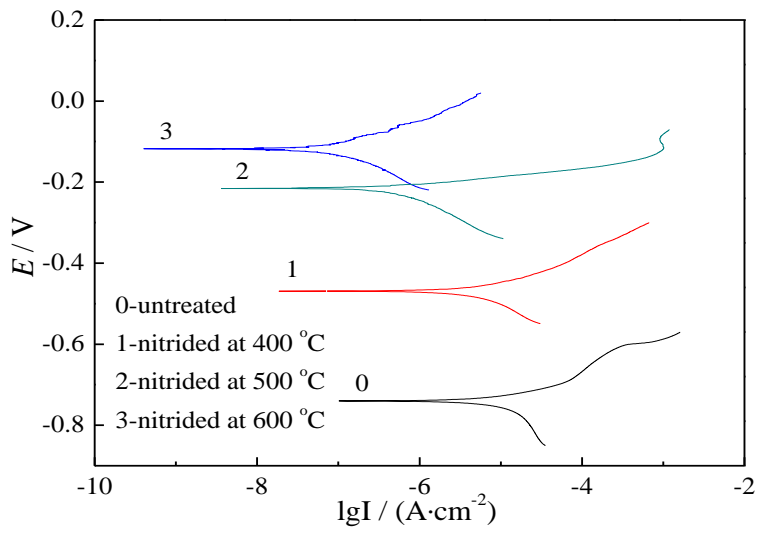

Figure 5. Anodic polarization curves of the high manganese TWIP steel in $3.5 \mathrm{wt}$ \% $\mathrm{NaCl}$ solution.

The grain distributions and texture orientations of the experimental steel sheets are shown in Figure 6. The EBSD observations reveal the existence of twins in both of the as-resaved and nitrited steel sheets. There is little difference in the grain size and occurrence frequency of twins in all the 
samples, thus the effect of grain size and twins on the corrosion resistance can be neglected. The inverse pole figure (IPF) maps indicate that a weak crystallographic texture is identified in the as-received steel sheet as shown in Figure 6a. After nitriding, the steel sheets show an obvious preferred orientation towards the $\{111\} / /$ ND as shown in Figure $6 b-d$.

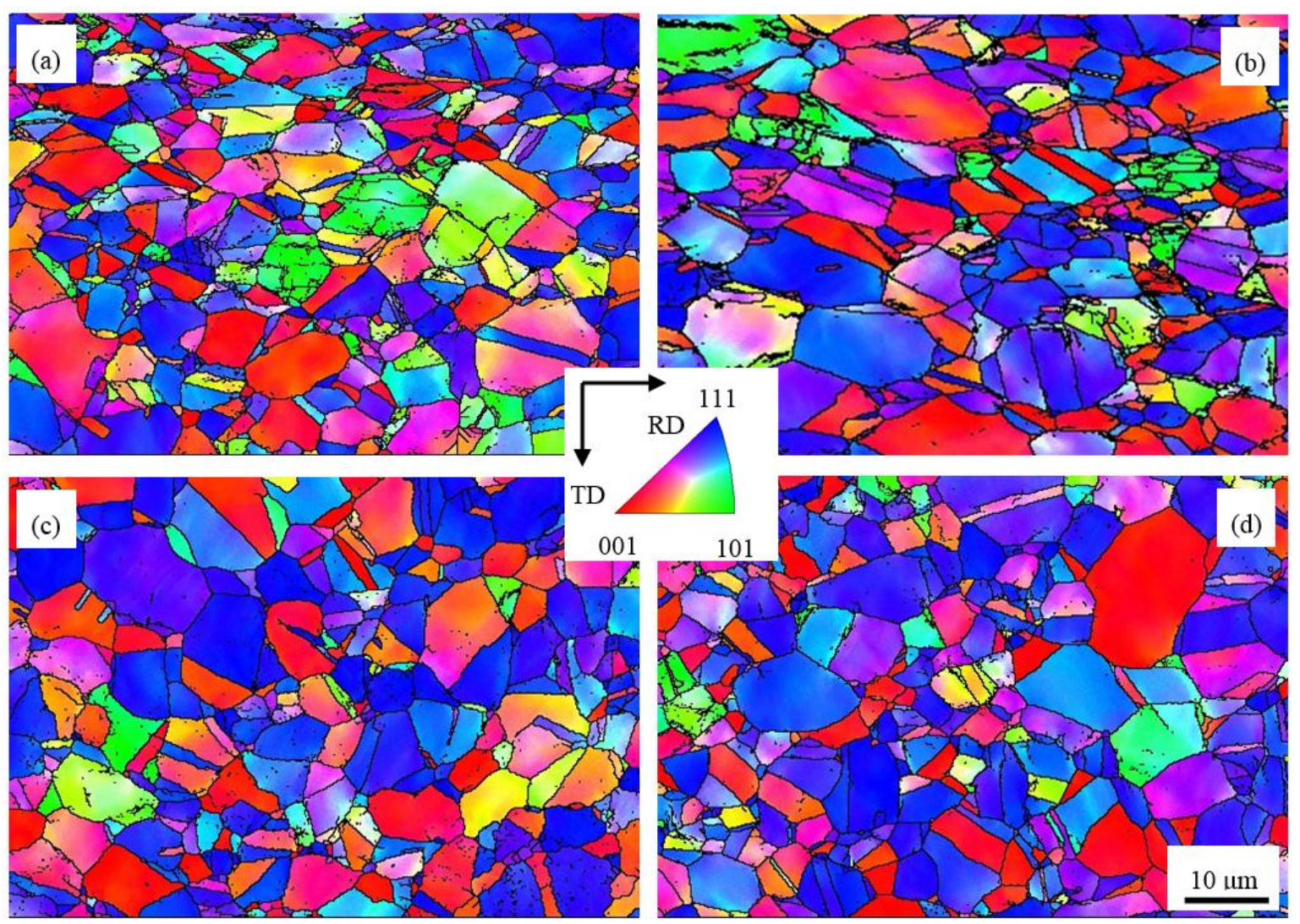

Figure 6. Electron back-scattered diffraction (EBSD) images of (a) as-resaved and the nitrided samples: (b) $400{ }^{\circ} \mathrm{C}$, (c) $500{ }^{\circ} \mathrm{C}$, (d) $600{ }^{\circ} \mathrm{C}$.

Figure 7 shows the distribution of $\{111\} /$ /ND oriented grains that obtained by EBSD analysis and the corresponding frequency are listed in Table 3. It was reported that for the face center cubic (fcc) crystal, the (111)-oriented grain had higher energy work function [34,35] and lower surface energy [36] than other oriented grains. Through these previous works, it can be concluded that (111)-oriented grains possess higher corrosion resistance in (fcc) crystal structure. The investigation done by Song et al. [37] found that the corrosion properties of N-doped austenitic fcc structure with strong (111)-preferred orientation were superior in $3.5 \mathrm{wt}$. \% NaCl. Thus, the improvement of the corrosion resistance of the nitrided steel sheets is caused by the increase of (111)-oriented grains in the surface of the studied steel.

Table 3. Characteristic data obtained from polarization curves.

\begin{tabular}{ccccc}
\hline Sample No. & $\begin{array}{c}\text { Nitrding } \\
\text { Temperature }\left({ }^{\circ} \mathbf{C}\right)\end{array}$ & $\begin{array}{c}\text { Frequency of (111) } \\
\text { Oriented Grains (\%) }\end{array}$ & Ecorr (V) & Icorr (A/cm $\left.{ }^{\mathbf{2}}\right)$ \\
\hline 0 & - & 38.0 & -0.77 & $1.9 \times 10^{-5}$ \\
1 & 400 & 46.6 & -0.54 & $1.8 \times 10^{-5}$ \\
2 & 500 & 48.7 & -0.30 & $1.2 \times 10^{-6}$ \\
3 & 600 & 53.7 & -0.21 & $5.2 \times 10^{-7}$ \\
\hline
\end{tabular}




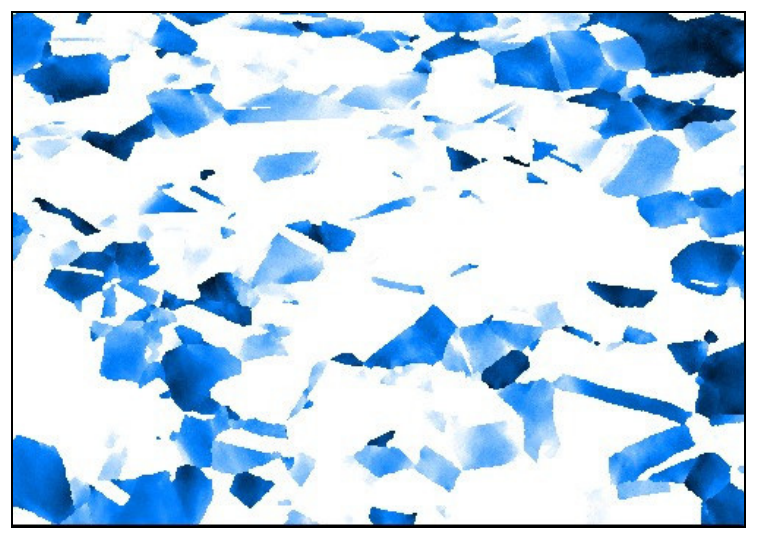

(a)

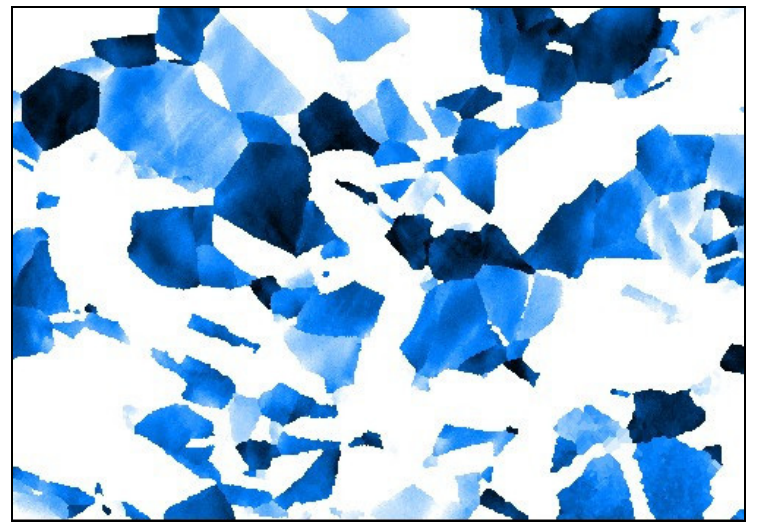

(c)

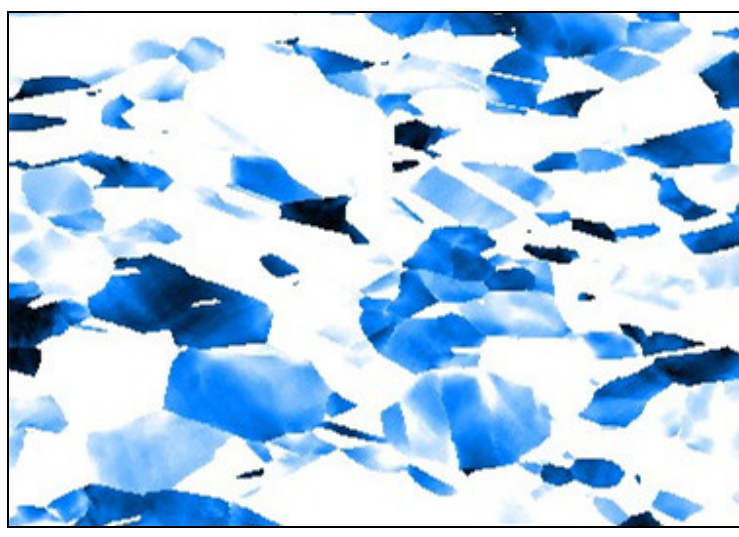

(b)

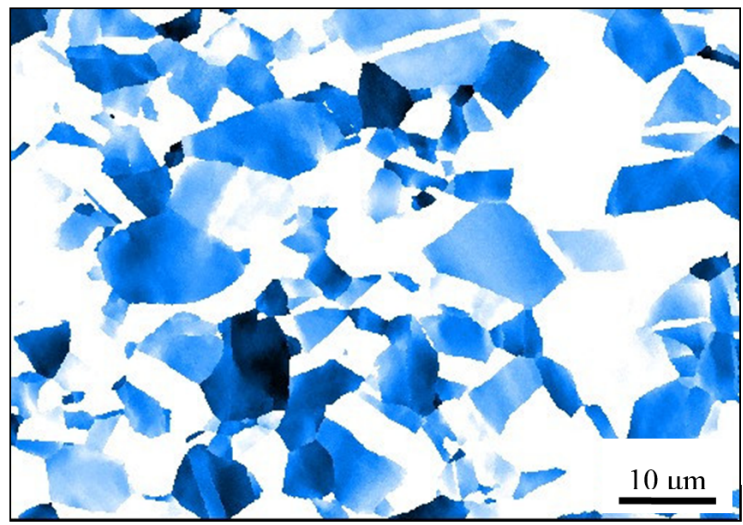

(d)

Figure 7. Distribution of $\{111\} /$ /ND oriented grains of the steel sheet (a) as-resaved and nitrided at (b) $400{ }^{\circ} \mathrm{C}$, (c) $500{ }^{\circ} \mathrm{C}$ and (d) $600{ }^{\circ} \mathrm{C}$.

\section{Conclusions}

1. The phase composition of the nitrided layers of the studied steel depends largely on the nitriding temperature. When the nitriding temperature is lower than $500^{\circ} \mathrm{C}$, the main composition of the modified layers is S-phase, while $\mathrm{Fe}_{4} \mathrm{~N}$ forms with S-phase at $600{ }^{\circ} \mathrm{C}$.

2. The anti-corrosion ability of the nitrided TWIP steel is better. Moreover, the elevated nitriding temperature has a positive effect on the anti-corrosion ability caused by the increasing of (111)-oriented grains in the surface of the nitrided steel sheets.

Acknowledgments: This work was financially supported by the Research Fund (Grant No. L20150168) from the Department of Education, Liaoning Province, P.R. China and the National Natural Science Fundation of China (No. 51501031) and the National High Technology Research and Development Program of China (Grant No. 2012AA03A508).

Author Contributions: Xiaoyun Yuan analyzed the experimental data and wrote the manuscript. Liqing Chen conceived and designed the experiments. Yang Zhao and Xing Li performed the experimental work. All authors have participated in the discussion of results.

Conflicts of Interest: The authors declare no conflict of interest.

\section{References}

1. Yetim, A.F.; Alsaran, A.; Çelik, A. Investigation of tribological and electrochemical properties of dual layer after low temperature plasma carbo-nitriding. Surf. Eng. 2010, 26, 178-184. [CrossRef] 
2. Christiansen, T.; Somers, M.A.J. Low temperature gaseous nitriding and carburising of stainless steel. Surf. Eng. 2004, 21, 445-455. [CrossRef]

3. Sueyoshi, H.; Hamaishi, K.; Nakamura, Y.; Kiyofuji, J. Effect of mechanical pre-treatment on gas nitriding behavior in austenitic stainless steels. Mater. Trans. JIM 1996, 37, 150-156. [CrossRef]

4. Heras, E.D.L.; Ybarra, G.; Lamas, D.; Cabo, A.; Dalibon, E.L. Plasma nitriding of 316L stainless steel in two different N2-H2 atmospheres-Influence on microstructure and corrosion resistance. Surf. Coat. Technol. 2017, 313, 47-54. [CrossRef]

5. Oztürk, O.; Williamson, D.L. Phase and composition depth distribution analyses of low energy, high flux N implanted stainless steel. J. Appl. Phys. 1995, 77, 3839-3850. [CrossRef]

6. Lei, M.K.; Zhang, Z.L.; Zhu, X.M. Effects of nitrogen-induced h.c.p. martensite formation on corrosion resistance of plasma source ion nitrided austenitic stainless steel. J. Mater. Sci. Lett. 1999, 18, 1537-1538. [CrossRef]

7. Sun, Y.; Bell, T.; Kolosvary, Z.; Flis, J. The response of austenitic stainless steels to low temperature plasma nitriding. Heat Treat. Metals 1999, 26, 9-16.

8. Menthe, E.; Bulak, A.; Olfe, J.; Zimmermann, A.; Rie, K.T. Improvement of the mechanical properties of austenitic stainless steel after plasma nitriding. Surf. Coat. Technol. 2000, 133, 259-263. [CrossRef]

9. Singh, V.; Marchev, K.; Cooper, C.; Meletis, E. Intensified plasma-assisted nitriding of AISI 316L stainless steel. Surf. Coat. Technol. 2002, 160, 249-258. [CrossRef]

10. Nosei, L.; Farina, S.; Ávalos, M.; Náchez, L.; Gómez, B.; Feugeas, J. Corrosion behavior of ion nitrided AISI 316L stainless steel. Thin Solid Films 2008, 516, 1044-1050. [CrossRef]

11. Ichii, K.; Fujimura, K.; Takase, T. Structure of the Ion-Nitrided Layer of 18-8 Stainless Steel. Technol. Rep. Kansai Univ. 1986, 27, 135-144.

12. Marchev, K.; Cooper, C.V.; Blucher, J.T.; Giessen, B.C. Conditions for the formation of a martensitic single-phase compound layer in ion-nitrided 316L austenitic stainless steel. Surf. Coat. Technol. 1998, 99, 225-228. [CrossRef]

13. Marchev, K.; Hidalgo, R.; Landis, M.; Vallerio, R.; Cooper, C.V.; Giessen, B.C. The metastable m phase layer on ion-nitrided austenitic stainless steels Part 2: Crystal structure and observation of its two-directional orientational anisotropy. Surf. Coat. Technol. 1999, 113, 67-70. [CrossRef]

14. Baranow, J. Characteristic of the nitride layers on the stainless steel at low temperature. Surf. Coat. Technol. 2004, 180, 145-149. [CrossRef]

15. Köster, K.; Kaestner, P.; Bräuer, G.; Hoche, H.; Troßmann, T.; Oechsner, M. Material condition tailored to plasma nitriding process for ensuring corrosion and wear resistance of austenitic stainless steel. Surf. Coat. Technol. 2013, 228, 615-618. [CrossRef]

16. Saker, A.; Leroy, C.; Michel, H.; Frantz, C. Properties of sputtered stainless steel-nitrogen coatings and structural analogy with low temperature plasma nitrided layers of austenitic steels. Mater. Sci. Eng. A 1991, 140, 702-708. [CrossRef]

17. Samandi, M.; Shedden, B.A.; Smith, D.I.; Collins, G.A.; Hutchings, R.; Tendy, J. Microstructure, corrosion and tribological behaviour of plasma immersion ion-implanted austenitic stainless steel. Surf. Coat. Technol. 1993, 59, 261-266. [CrossRef]

18. Williamson, D.L.; Ozturk, O.; Wei, R.; Wilbur, P.J. Metastable phase formation and enhanced diffusion in f.c.c. alloys under high dose, high flux nitrogen implantation at high and low ion energies. Surf. Coat. Technol. 1994, 65, 15-23. [CrossRef]

19. Menthe, E.; Rie, K.T.; Schultze, J.W.; Simson, S. Structure and properties of plasma-nitrided stainless steel. Surf. Coat. Technol. 1995, 74, 412-416. [CrossRef]

20. Hannula, S.P.; Nenonen, P.; Hirvonen, J.P. Surface structure and properties of ion-nitrided austenitic stainless steels. Thin Solid Films 1989, 181, 343-350. [CrossRef]

21. Lei, M.K.; Zhang, Z.L. Plasma source ion nitriding-a new low-temperature, low-pressure nitriding approach. J. Vac. Sci. Technol. A 1995, 13, 2986-2990. [CrossRef]

22. Parascandola, S.; Gunzel, R.; Grotzschel, R.; Richter, E.; Moller, W. Analysis of deuterium induced nuclear reactions giving criteria for the formation process of expanded austenite. Nucl. Instrum. Methods Phys. Res. Sec. B 1998, 136, 1281-1285. [CrossRef]

23. Singh, V.; Marchev, K.; Cooper, C.V.; Meletis, E.I. Intensified plasma-assisted nitriding of AISI 316L stainless steel. Surf. Coat. Technol. 2002, 160, 249-258. [CrossRef] 
24. Arslan, E.; İğdil, M.C.; Trabzon, L.; Kazmanl, K.; Gulmez, T. The corrosion behaviour of austenitic 316L stainless steel after low-T plasma nitridation in the physiological solutions. Plasma Process. Polym. 2007, 4, S717-S720. [CrossRef]

25. Yuan, X.Y.; Chen, L.Q.; Zhao, Y.; Di, H.S.; Zhu, F.X. Influence of annealing temperature on mechanical properties and microstructures of a high manganese austenitic steel. J. Mater. Process. Technol. 2015, 217, 278-285. [CrossRef]

26. Yuan, X.Y.; Yao, Y.T.; Chen, L.Q. High-temperature oxidation behavior of a high manganese austenitic steel Fe-25Mn-3Cr-3Al-0.3C-0.01N. Acta Metall. Sin. 2014, 27, 401-406. [CrossRef]

27. Moller, W.; Parascandola, S.; Telbizova, T.; Gunzel, R.; Richter, E. Surface processes and diffusion mechanisms of ion nitriding of stainless steel and aluminium. Surf. Coat. Technol. 2001, 136, 73-79. [CrossRef]

28. Riviere, J.P.; Meheust, P.; Villain, J.P.; Templier, C.; Cahoreau, M.; Abrasonis, G.; Pranevicious, L. High current density nitrogen implantation of an austenitic stainless steel. Surf. Coat. Technol. 2002, 158, 99-104. [CrossRef]

29. Adachi, S.; Ueda, N. Formation of S-phase layer on plasma sprayed AISI, 316L stainless steel coating by plasma nitriding at low temperature. Thin Solid Films 2012, 523, 11-14. [CrossRef]

30. Borgioli, F.; Fossati, A.; Galvanetto, E.; Bacci, T.; Pradelli, G. Glow discharge nitriding of AISI 316L austenitic stainless steel: Influence of treatment pressure. Surf. Coat. Technol. 2006, 200, 5505-5513. [CrossRef]

31. Yetim, A.F.; Yazici, M. Wear resistance and non-magnetic layer formation on 316L implant material with plasma nitriding. J. Bionic Eng. 2014, 11, 620-629. [CrossRef]

32. Koskinen, J.; Torri, P.; Hirvonen, J.; Mahiout, A.; Stanishevsky, A. Arc discharge deposition of stainless steel coatings at different nitrogen pressures. Surf. Coat. Technol. 1996, 80, 57-60. [CrossRef]

33. Christiansen, T.; Somers, M.A.J. Low Temperature Gaseous Nitriding and Carburising of Stainless Steel. Surf. Eng. 2004, 21, 445-455. [CrossRef]

34. Chelvayohan, M.; Mee, C. Work function measurements on (110), (100) and (111) surfaces of silver. J. Phys. C Solid State Phys. 2000, 15, 2305-2312. [CrossRef]

35. Gartland, P.; Berge, S.; Slagsvold, B. Photoelectric work function of a copper single crystal for the (100), (110), (111) and (112) faces. Phys. Rev. Lett. 1972, 28, 738-739. [CrossRef]

36. Skriver, H.L.; Rosengaard, N. Surface energy and work function of elemental metals. Phys. Rev. 1992, 46, 7157-7168. [CrossRef]

37. Song, Y.S.; Lee, J.H.; Lee, K.H.; Lee, D.Y. Corrosion properties of N-doped austenitic stainless steel films prepared by IBAD. Surf. Coat. Technol. 2005, 195, 227-233. [CrossRef]

(C) 2017 by the authors. Licensee MDPI, Basel, Switzerland. This article is an open access article distributed under the terms and conditions of the Creative Commons Attribution (CC BY) license (http:/ / creativecommons.org/licenses/by/4.0/). 